\title{
PENGARUH TIME PRESSURE, TINDAKAN SUPERVISI, AUDIT RISK, MATERIALITAS, PROSEDUR REVIEW, DAN KESADARAN ETIS TERHADAP PENGHENTIAN PREMATUR ATAS PROSEDUR AUDIT DI BPK-RI PERWAKILAN BALI
}

\author{
I Made Wianto Putra A.A. Raka Emas Wicahyani \\ Fakultas Ekonomi Universitas Warmadwewa, Denpasar, Bali \\ *E-Mail: ptekagrafisbali@gmail.com
}

DiPublikasi: 31/01/2018

DOI: $10.22225 / k r \cdot 9 \cdot 2 \cdot 479.77-84$

Halaman: 77-84

\begin{abstract}
The purpose of this study was to examine the effects of time pressure, audit risk, materiality, review procedures, and ethical awareness of premature termination of audit procedures. The research was conducted at BPK-RI Bali Representative. The number of samples used were 50 respondents. Data analysis techniques used in this study are instrument test, classical assumption test, and multiple linear regression analysis. Time pressure test results have a positive effect on premature termination of audit procedures. Supervision actions have a negative effect on premature termination of audit procedures. Audit risk positively affects the premature termination of audit procedures. Materiality positively affects premature discontinuation of audit procedures. Review procedures negatively impact the premature termination of audit procedures. Ethical awareness negatively affects the premature discontinuation of audit procedures.
\end{abstract}

Keywords: time pressure, supervision actions, audit risk, materiality, review procedures, ethical awareness, premature discontinuation of audit procedures

\begin{abstract}
Abstrak
Tujuan dari penelitian ini untuk menguji pengaruh time pressure, audit risk, materialitas, prosedur review, dan kesadaran etis terhadap penghentian prematur atas prosedur audit. Penelitian dilakukan di BPK-RI Perwakilan Bali. Jumlah sampel yang digunakan sebanyak 50 responden. Teknik analisis data yang digunakan dalam penelitian ini adalah uji instrumen, uji asumsi klasik, dan analisis regresi linear berganda. Hasil uji time pressure berpengaruh positif terhadap penghentian prematur atas prosedur audit. Tindakan supervisi berpengaruh negatif terhadap penghentian prematur atas prosedur audit. Audit risk berpengaruh positif terhadap penghentian prematur atas prosedur audit. Materialitas berpengaruh positif terhadap penghentian prematur atas prosedur audit. Prosedur review berpengaruh negatif terhadap penghentian prematur atas prosedur audit. Kesadaran etis berpengaruh negatif terhadap penghentian prematur atas prosedur audit.
\end{abstract}

Kata kunci: time pressure, tindakan supervisi, audit risk, materialitas, prosedur review, kesadaran etis, penghentian prematur prosedur audit

\section{PENDAHULUAN}

Fenomena pengurangan kualitas audit semakin marak terjadi pada masa ini, sehingga mengakibatkan berkurangnya kepercayaan masyarakat terhadap auditor sebagai pihak yang independen dalam mengaudit laporan keuangan. Pemerintah dan badanbadan profesional telah berupaya untuk menghentikan kegagalan auditor dengan meningkatkan perundang-undangan dan sistem pemerintahannya. Penghentian prematur (premature sign-off) atas prosedur audit merupakan salah satu bentuk perilaku yang terindikasi sebagai pengurangan dari kualitas audit. Praktik penghentian prematur atas prosedur audit berpengaruh langsung terhadap kualitas laporan audit yang dihasilkan auditor, apabila salah satu langkah dalam prosedur audit dihilangkan, maka kemungkinan auditor membuat judgement atau kesalahan pembuatan opini yang semakin tinggi.

Faktor yang menjadi penyebab terjadinya penghentian prematur atas prosedur audit tidak hanya disebabkan oleh faktor karakteristik personal auditor (faktor internal), akan tetapi juga dari faktor situsional saat melakukan audit yaitu faktor eksternal (Bayu, 2013:4). Praktik penghentian prematur atas prosedur audit banyak dilakukan auditor dalam kondisi time pressure, perncanaan supervisi yang kurang, faktor audit risk, materialitas, prosedur review, 
dan kesadaran etis. Badan Pemeriksaan Keuangan (BPK) sebagai satu-satunya lembaga pemeriksa ekternal keuangan negara dan peranannya perlu lebih dimantapkan sebagai lembaga yang independen dan profesional. Pemeriksaan yang dilakukan BPK-RI terkait lembaga pemerintahan, harus dilakukan dengan cermat sehingga dapat mendeteksi apabila terdapat penyimpangan yang mungkin terjadi.

Penelitian ini merupakan replikasi yang dilakukan oleh Bayu (2013) "Pengaruh Time Pressure, Risiko Audit, Materialitas, Dan Kesadaran Etis Terhadap Penghentian Prematur Atas Prosedur Audit Pada Kantor Akuntan Publik Semarang". Hasil penelitian menyatakan time pressure dan risiko audit secara parsial berpengaruh positif terhadap penghentian prematur atas prosedur audit. Sedangkan materialitas dan kesadaran etis secara parsial berpengaruh negatif terhadap penghentian prematur atas prosedur audit. Penelitian berbeda yang dilakukan oleh Haryanto (2015) "Faktor Eksternal Dan Internal Yang Memengaruhi Auditor Dalam Penghentian Prematur Atas Prosedur Audit Pada Kantor Akuntan Publik Makasar". Hasil penelitian menyatakan time pressure, risiko audit, dan prosedur review tidak berpengaruh secara signifikan terhadap penghentian prematur atas prosedur audit. Sedangkan materialitas dan locus of control berpengaruh signifikan secara positif terhadap penghentian prematur atas prosedur audit. Andi (2016 "Pengaruh Tekanan Waktu, Locus Of Control, Tindakan Supervisi, Dan Materialitas Terhadap Penghentian Prematur Atas Prosedur Audit Di Kantor Akuntan Publik Surakarta Dan Semarang", hasil penelitian menyatakan tekanan waktu tidak berpengaruh terhadap penghentian prematur atas prosedur audit. Sedangkan locus of control, tindakan supervisi, dan materialitas berpengaruh terhadap penghentian prematur atas prosedur audit.

Penelitian sebelumnya yang telah dilakukan menunjukkan hasil yang berbeda-beda sehingga menyebabkan adanya ambiguitas dalam pengambilan kesimpulan dan terkait faktor yang memengaruhi penghentian prematur atas prosedur audit selama ini lebih ditekankan kepada auditor yang bekerja pada Kantor Akuntan Publik (KAP). Fenomena ini membuat untuk dilakukan penelitian terkait dengan penghentian prematur atas prosedur audit, khususnya dari aspek time pressure, tindakan supervisi, audit risk, materialitas, prosedur review, dan kesadaran etis. Judul yang diangkat yaitu "Pengaruh Time Pressure, Tindakan Supervisi, Audit Risk, Materialitas, Prosedur Review, dan Kesadaran Etis Terhadap Penghentian Prematur Atas Prosedur Audit di BPKRI Perwakilan Bali”.

\section{TINAJUAN PUSTAKA, HIPOTESIS DAN KERANGKA PENELITIAN}

\section{A. Tinjauan Pustaka \\ 1. Teori Atribusi}

Teori atribusi merupakan perilaku seseorang yang dipengaruhi oleh faktor-faktor personal seperti kemampuan atau usaha dan oleh faktor-faktor situsional seperti keberuntungan, taraf kesukaran suatu tugas dan waktu yang dimiliki untuk menyelesaikan tugas (Febriana, 2016:5). Teori atribusi ini dapat digunakan sebagai dasar dalam menemukan faktor-faktor yang menyebabkan auditor melakukan penghentian prematur atas prosedur audit.

\section{Prosedur Audit}

Audit prosedur adalah langkah-langkah yang harus dijalankan auditor dalam melaksanakan pemeriksaan dan sangat diperlukan agar tidak melakukan penyimpangan dan dapat bekerja secara efesien dan efektif (Sukrisno, 2016:147). Prosedur audit yang disebutkan dalam standar tersebut, meliputi inspeksi, pengamatan, permintaan keterangan, konfirmasi, penelusuran, pemeriksaan bukti pendukung, penghitungan, scanning, pelaksanaan ulang, dan teknik audit berbantuan computer (Mulyadi, 2014:86)

\section{Penghentian Prematur Atas Prosedur Audit}

Penghentian prematur didefinisikan sebagai suatu keadaan yang menunjukkan auditor menghentikan satu atau beberapa langkah audit yang diperlukan dalam prosedur audit tanpa menggantikan dengan langkah yang lain. (Surya, 2013:15). Prematur Sign Off (Penghentian Prematur Prosedur Audit) diartikan sebagai suatu praktik ketika auditor mendokumentasikan prosedur audit secara lengkap tanpa benar-benar melakukannya atau mengabaikan/tidak melakukan beberapa prosedur audit yang disyaratkan tetapi auditor dapat memberikan opini atas suatu laporan keuangan (Haryanto, 2015:14).

\section{Time Pressure}

Auditor dituntut untuk melakukan efisiensi biaya dan waktu dalam melaksanakan audit. Akhir-akhir ini tuntutan tersebut semakin besar dan menciptakan time pressure atau tekanan waktu (Surya, 2013:16). Keberadaan tekanan waktu memaksa auditor untuk menyelesaikan tugas secepatnya/sesuai dengan anggaran waktu yang telah ditetapkan sehingga ada kemungkinan bagi auditor untuk melakukan pengabaian terhadap prosedur audit bahkan pemberhentian prosedur audit (Febriana 2016:2).

\section{Tindakan Supervisi}

Pernyataan tentang supervisi diatur dalam PSA No. 5 Tahun 2001 (SA Seksi 311: 311.1) menyebutkan bahwa pekerjaan harus direncanakan sebaik-baiknya dan jika digunakan asisten harus 
disupervisi dengan semestinya. Unsur supervisi adalah memberikan instruksi kepada asisten, tetap menjaga penyampaian informasi masalah-masalah penting yang dijumpai dalam audit, me-review pekerjaan yang dilaksanakan, dan menyelesaikan perbedaan pendapat di antara para staf auditor.

\section{Audit Risk}

Audit risk adalah risiko yang terjadi dalam hal auditor, tanpa disadari, tidak memodifikasi pendapatnya sebagaimana mestinya, atas suatu laporan keuangan yang mengadung salah saji material. (Mulyadi, 2014:165). Risiko audit yang dipakai dalam penelitian ini adalah risiko deteksi. Risiko deteksi adalah risiko bahwa auditor tidak dapat mendeteksi salah saji material yang terdapat dalam satu asersi (Sukrisno, 2016:151).

\section{Materialitas}

Materialitas adalah besarnya nilai yang dihilangkan atau salah saji informasi akuntansi, yang dilihat dari keadaan yang melingkupnya, dapat mengakibatkan perubahan atas atau pengaruh terhadap pertimbangan orang yang meletakkan kepercayaan terhadap informasi tersebut, karena adanya penghilangan atau salah saji (Mulyadi, 2014:158). Saat auditor menetapkan bahwa materialitas yang melekat pada suatu prosedur audit rendah, maka terdapat kecenderungan bagi auditor untuk mengabaikan prosedur audit tersebut.

\section{Prosedur Review}

Hasil review yang dilaksanakan melalui prosedur pengajuan pertanyaan dan analisis harus menjadi dasar yang memadai bagi akuntan untuk memberikan keyakinan, bahwa tidak ada modifikasi material yang harus dilakukan atas laporan keuangan (Halim, 2014:286). Pelaksanaan prosedur review yang baik akan meningkatkan kemungkinan terdeteksinya perilaku penyimpangan dalam audit seperti praktik penghentian prematur atas prosedur audit. Kemudahan pendeteksian ini akan membuat auditor berpikir dua kali ketika melakukan tindakan semacam penghentian prematur atas prosedur audit.

\section{Kesadaran Etis}

Kesadaran etis merupakan kemampuan individu untuk mengevaluasi dan mempertimbangkan nilanilai etika dalam suatu kejadian. Kemampuan untuk dapat mengidentifikasi perilaku etis dan tidak etis sangat berguna dalam semua profesi termasuk auditor (Bayu, 2013:29). Kesadaran etis adalah tanggapan atau penerimaan seseorang terhadap suatu peristiwa moral tertentu melalui suatu proses penentuan yang kompleks sehingga seseorang dapat memutuskan apa yang harus dilakukan pada situasi tertentu (Stefani, 2011:6). Motif kesadaran sangat penting dalam proses pengambilan keputusan karena merupakan sumber dari proses berpikir.

\section{B. HIPOTESIS}

\section{Pengaruh Time Pressure Terhadap Penghentian Prematur Atas Prosedur Audit}

Berdasarkan penelitian Bayu Prasetya (2013) dan Febriana (2016) time pressure secara parsial berpengaruh positif terhadap penghentian prematur atas prosedur audit. Berdasarkan hasil penelitian tersebut peneliti dapat menyusun hipotesis sebagai berikut:

H1: Time Pressure berpengaruh positif terhadap penghentian prematur atas prosedur audit.

\section{Pengaruh Tindakan Supervisi Terhadap Penghentian Prematur Atas Prosedur Audit}

Berdasarkan penelitian Andi Tri J. (2016) tindakan supervisi berpengaruh positif terhadap penghentian prematur atas prosedur audit. Peranan dari supervisi yang baik akan dapat meningkatkan kemungkinan terdeteksinya penghentian prematur atas prosedur audit yang merupakan sebagai salah satu bentuk penyimpangan perilaku audit (Fifi, 2015:2). Berdasarkan hasil penelitian tersebut peneliti dapat menyusun hipotesis sebagai berikut:

H2: Tindakan supervisi berpengaruh positif terhadap penghentian prematur atas prosedur audit.

\section{Pengaruh Audit Risk Terhadap Penghentian Prematur Atas Prosedur Audit}

Risiko audit yang dipakai dalam penelitian ini adalah risiko deteksi. Risiko deteksi adalah risiko bahwa auditor tidak dapat mendeteksi salah saji material yang terdapat dalam satu asersi (Sukrisno, 2016:151). Berdasarkan penelitian yang dilakukan Stefani Indarto (2011) dan Bayu Prasetya (2013) audit risk berpengaruh signifikan positif terhadap penghentian prematur atas prosedur audit Berdasarkan hasil penelitian tersebut peneliti dapat menyusun hipotesis sebagai berikut:

H3: Audit risk berpengaruh positif terhadap penghentian prematur atas prosedur audit.

\section{Pengaruh Materialitas Terhadap Penghentian Prematur Atas Prosedur Audit}

Berdasarkan penelitian yang dilakukan Haryanto (2015) dan Andi Tri J. (2016) materialitas berpengaruh signifikan positif terhadap penghentian prematur atas prosedur audit. Berdasarkan hasil penelitian tersebut peneliti dapat menyusun hipotesis sebagai berikut:

H4: Materialitas berpengaruh positif terhadap penghentian prematur atas prosedur audit. 


\section{Pengaruh Prosedur Review Terhadap Penghentian Prematur Atas Prosedur Audit}

Prosedur review terhadap hasil audit perlu dilakukan untuk mengantisipasi terjadinya perilaku disfungsional audit yang dilakukan auditor. Berdasarkan penelitian yang dilakukan Stefani (2011) dan Haryanto (2015) prosedur review berpengaruh signifikan negatif terhadap penghentian prematur atas prosedur audit. Berdasarkan hasil penelitian tersebut peneliti dapat menyusun hipotesis sebagai berikut:

H5: Prosedur review berpengaruh negatif terhadap penghentian prematur atas prosedur audit.

\section{Pengaruh Kesadaran Etis Terhadap Penghentian Prematur Atas Prosedur Audit}

Motif kesadaran akan membantu auditor dalam memprediksi suatu keputusan yang tidak terencana maupun ketika dihadapkan pada keputusan yang terencana dengan baik, agar dapat menghadapi risiko dan ketidakpastian dalam mengambil suatu tindakan, sehingga kemungkinan untuk terjadinya penghentian prematur atas prosedur audit dapat dihindarkan. Berdasarkan penelitian yang dilakukan Stefani (2011) dan Dwi Sulistyanto (2016) kesadaran etis secara signifikan berpengaruh negatif terhadap penghentian prematur atas prosedur audit. Berdasarkan hasil penelitian tersebut peneliti dapat menyusun hipotesis sebagai berikut:

H6: Kesadaran etis berpengaruh negatif terhadap penghentian prematur atas prosedur audit.

\section{KERANGKA PEMIKIRAN PENELITIAN}

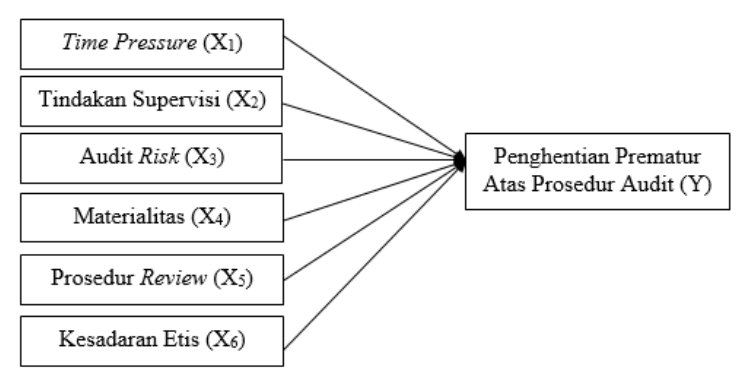

Diagram 1

Model Penelitian

\section{METODE PENELITIAN}

Tempat penelitian ini adalah pada BPK-RI Perwakilan Bali. Lokasi ini dipilih karena penelitian mengenai pengaruh time pressure, tindakan supervisi, audit risk, materialitas, prosedur review, dan kesadaran etis terhadap penghentian prematur atas prosedur audit di BPK-RI Perwakilan Bali relatif sedikit dilakukan.

Variabel yang digunakan dalam penelitian ini ada dua yaitu: a) Variabel Dependen (Variabel Terikat) adalah penghentian prematur prosedur audit (Y)

b) Variabel Independen (Variabel Bebas) adalah time pressure $(\mathrm{X} 1)$, tindakan supervisi $(\mathrm{X} 2)$, audit risk (X3), materialitas (X4), prosedur review (X5) dan kesadaran etis (X6)

\section{A. Definisi Operasional Variabel}

1) Time pressure merupakan suatu keadaan dimana auditor mendapatkan tekanan untuk menyelesaikan tugas secepatnya atau sesuai dengan anggaran waktu yang telah ditetapkan.

2) Tindakan supervisi merupakan suatu usaha merencanakan, mengatur, mengkoordinir, dan mengontrol yang bertujuan untuk mencapai hasil melalui orang lain yang mencakup pengarahan kegiatan pemeriksaan dan pihak lain agar tujuan pemeriksaan dapat tercapai.

3) Audit risk merupakan hal yang terkait dengan risiko deteksi, yang artinya suatu ketidakpastian yang dihadapi oleh auditor dengan kemungkinan bahwa bahan bukti yang dikumpulkan tidak mampu mendeteksi adanya salah saji material.

4) Materialitas merupakan besarnya salah saji dari informasi akuntansi yang dalam kondisi tertentu akan berpengaruh terhadap perubahan pengambilan keputusan yang diambil oleh para pengambil keputusan.

5) Prosedur review merupakan pemeriksaan terhadap kertas kerja audit yang terkait dengan pemberian opini sesuai dengan prosedur yang telah ditetapkan.

6) Kesadaran etis merupakan motif yang membantu auditor dalam memprediksi suatu keputusan yang tidak terencana maupun ketika dihadapkan pada keputusan yang terencana dengan baik, sehingga auditor tetap dapat menjaga integritasnya, kompetensi, dan independensi dalam setiap konflik kepentingan yang dihadapi.

\section{B. Jenis dan Sumber Data}

Jenis data yang digunakan dalam penelitian ini adalah dengan pendekatan kantitatif. Sumber data yang digunakan dalam penelitian ini adalah data primer yang diperoleh langsung dari sumbernya. Data primer dalam penelitian ini didapat dari kuesioner yang telah diisi oleh responden.

\section{Populasi dan Metode Pengumpulan Data}

Populasi dalam penelitian ini adalah seluruh auditor yang bekerja di Kantor Badan Pemeriksaan Keuangan (BPK) Republik Indonesia wilayah Bali. Metode pengumpulan data dalam penelitian ini 
menggunakan survey dengan teknik pengumpulan data dengan menggunakan angket (kuesioner). Skala pengukuran yang digunakan adalah skala bipolar adjective yaitu skala penyempurnaan dari semantic scale dengan harapan agar respon yang dihasilkan dapat diperoleh "intervally scalled data". Hanya memberikan dua kategori ekstrim dengan jangkauan nilai 1 sampai 10 responden dapat memberi jawaban pada rentang jawaban positif sampai dengan negatif.

\section{Teknik Analisis Data}

\section{Uji Instrument Penelitian}

a) Uji Validitas untuk mengukur sah atau valid tidaknya suatu kuesioner. Suatu instrument dikatakan Valid jika nilai r Pearson correlation terhadap skor total diatas 0,3 (Ghozali, 2016:52).

b) Uji Reliabilitas atau keandalan instrument menunjukkan sejauh mana suatu pengukuran dapat memberikan hasil yang konsisten. Uji reliabilitas dilakukan terhadap instrument yang koefesien cronbach'c alpha lebih besar dari 0,70 maka instrument yang digunakan reliable (Ghozali, 2016:48).

\section{Uji Asumsi Klasik}

a) Uji Normalitas dilakukan untuk menguji apakah pada residual dari model regresi yang telah dibuat berdistribusi normal atau tidak. Data populasi dikatatakan berdistribusi normal jika Koefisien Asym.Sig (2-tailed) lebih besar dari 0,05 (Ghozali, 2016:154).

b) Uji Multikolinearitas dapat dilihat dari nilai tolerance atau varians inflation factor (VIF). Jika nilai tolerance lebih besar dari $10 \%$ atau VIF kurang dari 10, maka dapat dikatakan model telah bebas dari masalah multikolinearitas (Ghozali, 2016:107).

c) Uji Heteroskedastisitas dilakukan dengan meregresikan variabel bebas terhadap nilai absolute residual. Model regresi tidak mengandung heteroskedastisitas apabila nilai signifikan variabel terhadap nilai absolute residual statistik diatas $a=0,05$ (Ghozali, 2016:134).

\section{Analisis Regresi Linear Berganda}

Pengujian hipotesis dilakukan dengan menggunakan analisis regresi berganda untuk mengetahui atau memperoleh gambaran mengenai pengaruh variabel independen terhadap variabel dependen. Model regresi linear berganda yang digunakan adalah dengan menggunakan rumus: a) Uji Signifikansi Simultan (Uji Statistik F) untuk melihat pengaruh variabel-variabel independen secara simultan terhadap variabel dependen. Kriteria pengambilan keputusan yaitu dengan melihat $\mathrm{F}$ hitung lebih besar dari 4 pada probabilitas $a=0,05$ maka variabel independen berpengaruh terhadap variabel dependen (Ghozali, 2016:99).

b) Uji Statistik t untuk mengetahui seberapa besar pengaruh dari variabel-variabel bebas secara individual dapat menerangkan variasi variabel dependen. Hasil pengujian kemudian dibandingkan dengan tingkat signifikansi menggunakan taraf nyata $a$ sebesar $5 \%$ (Ghozali, 2016:99).

\section{ANALISIS DATA DAN PEMBAHASAN}

\section{A. Analisis Data}

\section{Uji Instrumen Penelitian}

Hasil perhitungan validitas menunjukkan bahwa nilai korelasi pada setiap butir kuisioner pada variabel penelitian memiliki nilai lebih besar dari 0,3 sehingga dapat dijelaskan bahwa semua butir kuisioner yang digunakan pada setiap variabel telah memenuhi syarat validitas dan dapat digunakan sebagai alat pengumpulan data penelitian.

Hasil perhitungan reliabilitas menunjukkan bahwa nilai cronbach's alpha untuk setiap variabel penelitian menunjukkan bahwa nilai cronbach's alpha $>0,70$, hal ini menunjukkan bahwa instrument yang digunakan dalam penelitian ini adalah reliabel.

\section{Uji Asumsi Klasik}

Hasil pengujian normalitas data dengan onesample kolmogorov-smirnov test diperoleh nilai Asymp.Sig (2-tailed) sebesar 0,087 lebih besar dari 0,05 , menunjukkan bahwa data yang digunakan dalam persamaan regresi linier berganda merupakan data yang berdistribusi normal.

Hasil pengujian multikolinearitas data menunjukkan nilai tolerance pada semua variabel penelitian lebih besar dari 0,1 dan nilai Variance Inflamation Factor lebih kecil dari 10, sehingga dapat dijelaskan bahwa data yang digunakan dalam penelitian ini merupakan data yang terbebas dari gejala multikolinearitas.

Hasil pengujian heteroskedastisitas menunjukan nilai signifikansi semua variabel bebas berdasarkan nilai absolut residual sebagai variabel dependen menunjukkan nilai signifikan lebih besar dari 0,05 sehingga dapat dijelaskan bahwa data yang digunakan dalam penelitian ini merupakan data yang bebas dari gejala heteroskedastisitas.

\section{Analisis Regresi Linear Berganda}


Tabel 1

Hasil Analisis Regresi Linier Berganda

\begin{tabular}{|c|c|c|c|c|c|}
\hline \multirow[b]{2}{*}{ Model } & \multicolumn{2}{|c|}{$\begin{array}{c}\text { Unstandardized } \\
\text { Coefficients }\end{array}$} & \multirow{2}{*}{$\begin{array}{c}\begin{array}{r}\text { Standardized } \\
\text { Coefficients }\end{array} \\
\text { Beta } \\
\end{array}$} & \multirow[b]{2}{*}{$\mathrm{t}$} & \multirow[b]{2}{*}{ Sig. } \\
\hline & $\mathrm{B}$ & Std. Error & & & \\
\hline \begin{tabular}{l|l}
1 & (Constant)
\end{tabular} & 23.917 & 9.689 & & 2.468 & .018 \\
\hline $\begin{array}{l}\text { Time } \\
\text { Pressure } \\
\end{array}$ & .487 & .213 & .217 & 2.287 & .027 \\
\hline $\begin{array}{l}\text { Tindakan } \\
\text { Supervisi }\end{array}$ & -.188 & .087 & -.133 & -2.173 & .035 \\
\hline Audit Risk & 1.065 & .252 & .274 & 4.217 & .000 \\
\hline Materialitas & 1.046 & .308 & .271 & 3.394 & .001 \\
\hline $\begin{array}{l}\text { Prosedur } \\
\text { Review }\end{array}$ & -.269 & .076 & -.121 & -3.542 & .001 \\
\hline $\begin{array}{l}\text { Kesadaran } \\
\text { Etis }\end{array}$ & -.262 & .126 & -.161 & -2.081 & .043 \\
\hline
\end{tabular}

Sumber: Lampiran 8

Pada pengujian analisis regresi linier berganda diperoleh persamaan regresi linier berganda sebagai berikut:

$\mathrm{Y}=23,917+0,487 \mathrm{X}_{1}-0,188 \mathrm{X}_{2}+1,065 \mathrm{X}_{3}+1,046 \mathrm{X}_{4}-0,269 \mathrm{X}_{5}-0,262 \mathrm{X}_{6}$

Berdasarkan persamaan regresi linear berganda tersebut dapat diartikan koefisien-koefisien sebagai berikut:

a) Nilai koefisien variabel time pressure sebesar 0,487, memiliki makna jika time pressure mengalami peningkatan maka penghentian prematur atas prosedur audit akan bertambah.

b) Nilai koefisien variabel tindakan supervisi sebesar -0,188, memiliki makna jika tindakan supervisi mengalami peningkatan maka penghentian prematur atas prosedur audit akan berkurang.

c) Nilai koefisien variabel audit risk sebesar 1,065, memiliki makna jika audit risk mengalami peningkatan maka penghentian prematur atas prosedur audit akan bertambah.

d) Nilai koefisien variabel materialitas sebesar 1,046, memiliki makna jika materialitas mengalami peningkatan maka penghentian prematur atas prosedur audit akan bertambah.

e) Nilai koefisien variabel prosedur review sebesar -0,269, memiliki makna jika prosedur review mengalami peningkatan maka penghentian prematur atas prosedur audit akan berkurang.

f) Nilai koefisien variabel kesadaran etis sebesar 0,262, memiliki makna jika kesadaran etis mengalami peningkatan maka penghentian prematur atas prosedur audit akan berkurang.

\section{Uji Signifikansi Simultan (Uji Statistik F)}

Berdasarkan hasil pengujian secara simultan diperoleh nilai $F$ sebesar 142,097 dengan nilai signifikan $0,000<0,05$. Hal ini menunjukkan bahwa terdapat pengaruh yang signifikan secara simultan variabel time pressure, tindakan supervisi, audit risk, materialitas, prosedur review, dan kesadaran etis terhadap penghentian prematur atas prosedur audit.

\section{Uji Statistik t}

Berdasarkan hasil uji $\mathrm{t}$ diperoleh nilai t hitung pada variabel time pressure sebesar 2,287 dengan nilai signifikan $0,027<0,05$ artinya bahwa terdapat pengaruh yang signifikan secara parsial antara time pressure terhadap penghentian prematur atas prosedur audit.

Berdasarkan hasil uji $\mathrm{t}$ diperoleh nilai $\mathrm{t}$ hitung pada variabel tindakan supervisi sebesar $-2,173$ dengan nilai signifikan $0,035<0,05$ artinya bahwa terdapat pengaruh yang signifikan secara parsial antara tindakan supervisi terhadap penghentian prematur atas prosedur audit.

Berdasarkan hasil uji t diperoleh nilai t hitung pada variabel audit risk sebesar 4,217 dengan nilai signifikan $0,000<0,05$ artinya bahwa terdapat pengaruh yang signifikan secara parsial antara audit risk terhadap penghentian prematur atas prosedur audit.

Berdasarkan hasil uji t diperoleh nilai t hitung pada variabel materialitas sebesar 3,394 dengan nilai signifikan $0,001<0,05$ artinya bahwa terdapat pengaruh yang signifikan secara parsial antara materialitas terhadap penghentian prematur atas prosedur audit.

Berdasarkan hasil uji t diperoleh nilai t hitung pada variabel prosedur review sebesar -3,542 dengan nilai signifikan $0,001<0,05$ artinya bahwa terdapat pengaruh yang signifikan secara parsial antara prosedur review terhadap penghentian prematur atas prosedur audit.

Berdasarkan hasil uji t diperoleh nilai t hitung pada variabel kesdaran etis sebesar -2,081 dengan nilai signifikan $0,034<0,05$ artinya bahwa terdapat pengaruh yang signifikan secara parsial antara kesadaran etis terhadap penghentian prematur atas prosedur audit.

\section{B. Pembahasan dan Hasil Penelitian}

1. Pengaruh Time Pressure Terhadap Penghentian Prematur Atas Prosedur Audit

Time pressure berpengaruh positif terhadap penghentian prematur atas prosedur audit di BPK-RI Perwakilan Bali. Hal ini mengindikasikan bahwa peningkatan pada variabel time pressure akan diikuti peningkatan pada penghentian prematur atas prosedur audit pada BPK-RI Perwakilan Bali yang dibuktikan dengan nilai signifikan sebesar 0,027< 0,05 . 
2. Pengaruh Tindakan Supervisi Terhadap Penghentian Prematur Atas Prosedur Audit

Tindakan supervisi berpengaruh negatif terhadap penghentian prematur atas prosedur audit di BPK-RI Perwakilan Bali. Hal ini mengindikasikan bahwa peningkatan pada variabel tindakan supervisi akan diikuti penurunan pada penghentian prematur atas prosedur audit pada BPK-RI Perwakilan Bali yang dibuktikan dengan nilai signifikan sebesar $0,035<$ 0,05 .

\section{Pengaruh Audit Risk Terhadap Penghentian Prematur Atas Prosedur Audit}

Audit risk berpengaruh positif terhadap penghentian prematur atas prosedur audit di BPK-RI Perwakilan Bali. Hal ini mengindikasikan bahwa peningkatan pada variabel audit risk akan diikuti peningkatan pada penghentian prematur atas prosedur audit pada BPK-RI Perwakilan Bali yang dibuktikan dengan nilai signifikan sebesar $0,000<$ 0,05 .

\section{Pengaruh Materialitas Terhadap Penghentian Prematur Atas Prosedur Audit}

Materialitas berpengaruh positif terhadap penghentian prematur atas prosedur audit di BPK-RI Perwakilan Bali. Hal ini mengindikasikan bahwa peningkatan pada variabel materialitas akan diikuti peningkatan pada penghentian prematur atas prosedur audit pada BPK-RI Perwakilan Bali yang dibuktikan dengan nilai signifikan sebesar 0,001< 0,05 .

\section{Pengaruh Prosedur Review Terhadap Penghentian Prematur Atas Prosedur Audit}

Prosedur review berpengaruh negatif terhadap penghentian prematur atas prosedur audit di BPK-RI Perwakilan Bali. Hal ini mengindikasikan bahwa peningkatan pada variabel prosedur review akan diikuti penurunan pada penghentian prematur atas prosedur audit pada BPK-RI Perwakilan Bali yang dibuktikan dengan nilai signifikan sebesar 0,001< 0,05 .

\section{Pengaruh Kesadaran Etis Terhadap Penghen- tian Prematur Atas Prosedur Audit}

Kesadaran etis berpengaruh negatif terhadap penghentian prematur atas prosedur audit di BPK-RI Perwakilan Bali. Hal ini mengindikasikan bahwa penuruna pada variabel kesadaran etis akan diikuti penurunan pada penghentian prematur atas prosedur audit pada BPK-RI Perwakilan Bali yang dibuktikan dengan nilai signifikan sebesar $0,043<0,05$.

\section{SIMPULAN DAN SARAN}

\section{A. Simpulan}

Simpulan yang dapat diberikan berdasarkan hasil penelitian yang dilakukan pada BPK RI-Perwakilan Bali adalah sebagi berikut:

1. Time pressure berpengaruh positif terhadap penghentian prematur atas prosedur audit di BPK-RI Perwakilan Bali.

2. Tindakan supervisi berpengaruh negatif terhadap penghentian prematur atas prosedur audit di BPK-RI Perwakilan Bali.

3. Audit Risk berpengaruh positif terhadap penghentian prematur atas prosedur audit di BPK-RI Perwakilan Bali.

4. Materialitas berpengaruh positif terhadap penghentian prematur atas prosedur audit di BPK-RI Perwakilan Bali.

5. Prosedur review berpengaruh negatif terhadap penghentian prematur atas prosedur audit di BPK-RI Perwakilan Bali.

6. Kesadaran etis berpengaruh negatif terhadap penghentian prematur atas prosedur audit di BPK-RI Perwakilan Bali.

\section{B. Saran}

1. Kepada peneliti selanjutnya agar dapat mempertimbangkan untuk menggunakan objek penelitian yang berbeda atau dapat meneliti pada instansi yang lain untuk mendapatkan perbandingan dari hasil penelitian.

2. Penelitian selanjutnya dapat menambahkan variabel lainnya, seperti professional commitment dan locus of control.

\section{DAFTAR PUSTAKA}

Aini, Fifi Aprilia Nurul. 2015. Pengaruh Tekanan Waktu, Tindakan Supervisi, Locus Of Control Terhadap Penghentian Prematur. Jurnal Ilmu dan Riset Akuntansi Volume 4. Nomor 3.

Aji, Bayu Prasetya. 2013. Pengaruh Time Pressure, Risiko Audit, Materialitas, dan Kesadaran Etis Terhadap Penghentian Prematur Atas Prosedur Audit. Skripsi. Semarang: Program Sarjana Fakultas Ekonomi Universitas Semarang.

Andani, Ni Made Surya. 2013. Pengaruh Time Pressure, Audit Risk, Professional Commitment dan Locus of Control Pada Penghentian Prematur Prosedur Audit. Skripsi. Denpasar: Fakultas Ekonomi dan Bisnis Universitas Udayana.

Ghozali, Imam. 2016. Aplikasi Analisis Multivariate dengan Program IBM SPSS 23. Edisi ke-8, Semarang: Universitas Diponogoro.

Halim, Abdul. 2014. Dasar-Dasar Prosedur Pengau- 
ditan Laporan Keuangan. Jilid Dua. Edisi Keempat. Yogyakarta: UPP STIM YKPN

Haryanto, SM. 2015. Faktor Eksternal dan Internal yang Memengaruhi Auditor dalam Penghentian Prematur Atas Prosedur Audit. Skripsi. Makassar: Program Sarjana Fakultas Ekonomi dan Bisnis Universitas Hasanuddin.

Indarto, Stefani Lily. 2011. Analisis Faktor-Faktor Yang Mempengaruhi Penghentian Prematur Atas Prosedur Audit. Dinamika Sosial Ekonomi Volume 7. Nomor 2. Edisi November 2011

Junaidi, Andi Tri. 2016. Pengaruh Tekanan Waktu, Locuf Of Control, Tindakan Supervisi, dan Materialitas Terhadap Penghentian Prematur Atas Prosedur Audit. Skripsi. Surakarta: Program Studi Akuntansi Fakultas Ekonomi dan Bisnis Universitas Muhammadiyah Surakarta.

Kasigwa, Gerald. 2013. Reduced Audit Quality Behavior Among Auditors In Uganda. African Journal of Accounting, Economics, Finance and Banking Research Vol. 9. No. 9.

Kusumaningrum, Febriana. 2016. Pengaruh Tekanan Waktu, Tindakan Supervisi, Risiko Audit, Locus Of Control, dan Komitmen Organisasi Terhadap Penghentian Prematur Atas Prosedur Audit. Skripsi. Surakarta: Program Studi Akuntansi Fakultas Ekonomi dan Bisnis Universitas Muhammadiyah Surakarta.

Lubis, Arfan Ikhsan. 2011. Akuntansi Keperilakuan.
Edisi Kedua. Jakarta: Salemba Empat.

Mulyadi. 2014. Auditing Buku 1. Edisi keenam. Salemba Empat

Sulistyanto, Dwi. 2016. Pengaruh Time Pressure, Risioko Audit, Materialitas, Prosedur Review Dan Kontrol Kualitas, Locus Of Control, Komitmen Organisasi, Komitmen Profesional, Pengalaman Audit, Kesadara Etis Terhadap Penghentian Prematur Atas Prosedur Audit. Skripsi: Program Studi Akuntansi Fakultas Ekonomi Universitas Muria Kudus.

Sugiyono. 2016. Metode Penelitian Kuantitatif, Kualitatif, dan R\&D. Alfabeta. Bandung.

Sukrisno. Agoes. 2016. Auditing Petunjuk Praktis Pemeriksaan Akuntan Oleh Kantor Akuntan Publik. Buku 4. Edisi Ke 1. Jakarta: Salemba Empat.

Priyanto. 2014. Faktor-Faktor Yang Mempengaruhi Penghentian Prematur Atas Prosedur Audit. Program Studi Akuntansi Fakultas Ekonomi dan Bisnis Universitas Katolik Soegijapranata Semarang.

Wulandari, Devi. 2015. Pengaruh Tekanan Waktu, Tindakan Supervisi, dan Risiko Audit Terhadap Penghentian Preamtur Atas Prosedur Audit. Skripsi. Surakarta: Program Studi Akuntansi Fakultas Ekonomi dan Bisnis Universitas Muhammadiyah Surakarta.

www.bpk.go.id 